\title{
MONITORING BUTTERFLY BIODIVERSITY ON PRIME BUTTERFLY AREA Avala Mt. (Serbia) BY THE TRANSECT METHOD (Pollard Walks) IN THE YEAR 2017
}

\author{
PREDRAG JAKŠIĆ ${ }^{*}$, FRANC JANŽEKOVIČ ${ }^{2}$, TINA KLENOVŠEK ${ }^{2}$ \\ ${ }^{1}$ Faculty of Natural Sciences and Mathematics, University of Priština, Kosovska Mitrovica, Serbia \\ ${ }^{2}$ Department of Biology, Faculty of Natural Sciences and Mathematics, University of Maribor, Maribor, Slovenia
}

\begin{abstract}
An inventory of butterfly fauna was carried out in 2017 within the north-western part of the Prime Butterfly Area "Avala Mt.". Butterfly fauna was surveyed with a transect method from March until October within three sectors with different land use and plant succession. We evaluated the sectors by butterfly species richness, abundance of individuals, species accumulation curves, Shannon index, ecological and zoogeographical characteristics. A total of 1147 individuals were recorded, representing 50 species. Three new species (Pieris mannii (Mayer, 1851), Satyrium acaciae (Fabricius, 1787) and Kirinia roxelana (Cramer, 1777)) for the fauna of Avala Mt. were discovered that now counts 114 species. Abandoned dry grasslands in the process of secondary succession supported the highest number of species and individuals. Nevertheless, the observed butterfly species on Avala Mt. were almost equally characteristic for grasslands $(\mathbf{3 8 . 4 \%})$ and forests $(\mathbf{3 4 . 3 \%})$. In conclusion, butterfly biodiversity on Avala Mt. depends on habitat diversity, which is a combination of climax forest vegetation as well as formerly agricultural landscapes in different stages of secondary succession.
\end{abstract}

Keywords: Papilionoidea, Pollard Walks, Species Accumulation Curve, Secondary Succession, Serbia.

\section{INTORODUCTION}

During the last 100 years, only four papers were published dealing with the butterfly fauna of Avala Mountain (Gušić, 1923; Gradojević, 1930-31; Moucha, 1966; Anđus, 2008). A recent review paper with comprehensive data on 111 butterfly species of the Avala Mt. was published by Jakšić (2015).

Avala Mountain is situated $16 \mathrm{~km}$ south east from Belgrade, Serbia. The protected natural resource "Avala" (the landscape of outstanding features) is one of the Prime Butterfly Areas (PBA) in Serbia (Jakšić et al., 2008) with 6 species threatened on national or European level. It is located in the territory of the City of Belgrade. This low island-like mountain is made of serpentinite, flysch and loam deposits (Dimitrijević, 1931).

According to Fukarek \& Jovanović (1986), natural potential vegetation of Avala is Quercetum frainetto-ceris s. lat. and Querco-Carpinetum s. lat. According to Bohn and Neuhäusl (2000-2003) natural potential vegetation is PannonianDanubian-Balkan lowland to submontane Balkan oak-bitter oak forests (G19-G24).

Among 30 described habitat types (EUNIS habitat types), Balkano-Anatolian thermophilous oak forests, Moesio-Danubian xerothermal oak forests and Sub-Pannonic steppes (as fragments) were present as dominant types on the examined area.

The purpose of this study was to examine butterfly biodiversity of the Avala Mt. within areas with different land use and plant succession during one season with emphasis on species richness, abundance of individuals, ecological and zoogeographical characteristics.

\section{MATERIALS AND METHODS}

The investigated area on the Avala Mt., just above the village Beli Potok, was divided into three sectors A, B and C (Fig. 2). Originally, all sectors were covered by associations Rusco aculeati-Carpinetum betuli (Jovanović, 1979) and Fraxino orni-Quercetum virgilianae (Gajić, 1955). These associations were changed by human activities, mostly agriculture. Sector A was partly planted with Robinia pseudoacacia $\mathrm{L}$. and sector C with Scots and black pines. Sector B was covered mostly by natural potential vegetation. In sector $\mathrm{A}$, agriculture was abandoned 20 years ago and secondary succession was ongoing. In sector $\mathrm{C}$, the land was arable, but agriculture was abandoned 3-4 years ago (Fig. 1).

The method of quantitative monitoring was a "Pollard Walk" transect counting method (Pollard, 1977). Routes of transects were laid out to sample representative habitats parallel to the slopes. Transect counts were conducted at a moderate walking pace in a time interval of approximately 14 days (first count on 21st March, last on 21st October 2017, Tab. 1). Counts were realized on mostly sunny days from 10:00 am to 13:00 pm. Only species and specimens observed within the five meter strip on each side of the route had been registered. Counts and determination of butterflies were done by the first author.

\footnotetext{
* Corresponding author: jaksicpredrag@ gmail.com 

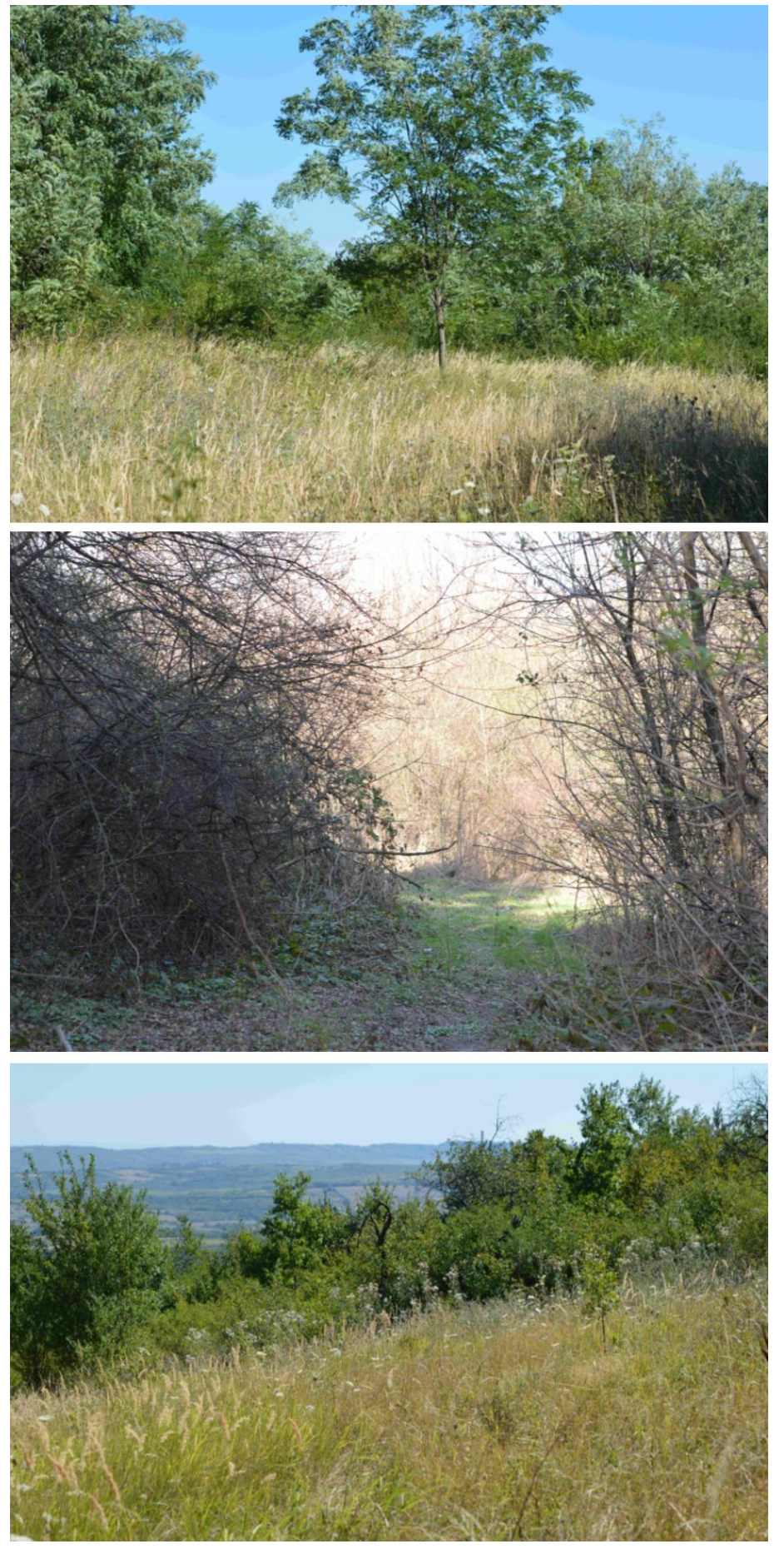

Figure 1. Examined sectors on Avala Mt.: grassland in secondary succession - sector A (above), natural potential forest vegetation - B (middle), abandoned field in secondary succession - C (below) (All photos P. Jakšić).

The map of Avala Mt. was done by software packages QGIS and INKSCAPE (Fig. 2). Positions and coordinates, at which Lepidoptera were caught, were determined using a Garmin e-Trex 10 Vista GPS device. According to the length of the area, longitude and latitude coordinates were between: 41' 54.5 " N; 31' 27.3" E (altitude $324 \mathrm{~m}$ ) and 42' 00.0" N; 31' 03.0" E (altitude $267 \mathrm{~m}$ ). Surface area was approximately 800 x $200 \mathrm{~m}$.
The in situ photos of specimens were taken using Nikon Camera with AF-S Micro Nikkor Lens.

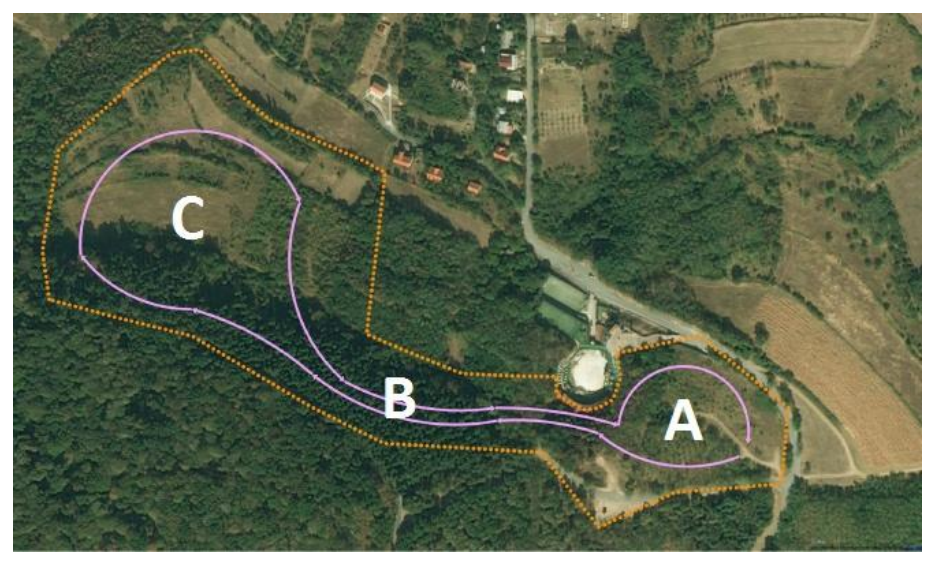

Figure 2. Study area map above Beli Potok village. Dotted line represents a border of the examined area on the Avala Mt. Continuous line represents transect routes. A, B and C indicate transect sectors.

The climate of Avala Mt. is mild-continental with a great continental influence. There is a short period of semi drought during July and August. In January and February, average temperatures are below $0{ }^{\circ} \mathrm{C}$ and frost can appear from late October to early April (Anonymous, 2017). The period from May to September, with average temperatures over $15{ }^{\circ} \mathrm{C}$, is characterized by full activity of Lepidoptera.

Taxonomic classification was done according to Nieukerken et al., (2011) and nomenclature according to Kudrna et al., (2015). Butterfly species were categorized according to habitat temperature preference (Mihut \& Dincã, 2004), trophic specialisation of caterpillars (Stefanescu et al., 2011), habitat types (van Swaay et al., 2006) and zoogeographical characteristics or faunal elements (Kudrna et al., 2011).

Butterfly fauna was statistically evaluated for the three sectors by species richness and abundance of individuals per sampling unit, number of singletons and Shannon index. Species accumulation curves were drawn with the EstimateS program (Colwell, 2013). The numbers of species and individuals were correlated to temperature with a nonlinear regression model Lowess (Statistica, 2004) and (Karadžić \& Marinković, 2009).

Fieldwork in a protected area was done on the basis of permits provided by the Ministry of Environment, Mining and Spatial Planning, Republic of Serbia, No. 353-01-834/2017-17, dated from 11.05. 2017. 
Table 1. Overview of realized transects showing the number of species identified by sectors and the total number of species observed.

\begin{tabular}{|c|c|c|c|c|}
\hline \multirow{2}{*}{$\begin{array}{c}\text { Date of sampling } \\
\text { units }\end{array}$} & \multicolumn{3}{|c|}{$\begin{array}{c}\text { Transect sectors and } \\
\text { number of species }\end{array}$} & $\begin{array}{c}\text { The total } \\
\text { number of } \\
\text { species }\end{array}$ \\
\cline { 2 - 4 } & A & B & C & 3 \\
\hline 21 March 2017 & 3 & 0 & 1 & 10 \\
\hline 2 April 2017 & 9 & 4 & 7 & 13 \\
\hline 11 April 2017 & 7 & 7 & 5 & 14 \\
\hline 26 April 2017 & 6 & 7 & 7 & 13 \\
\hline 14 May 2017 & 8 & 6 & 4 & 9 \\
\hline 28 May 2017 & 7 & 2 & 3 & 25 \\
\hline 11 June 2017 & 20 & 10 & 10 & 29 \\
\hline 23 June 2017 & 25 & 12 & 20 & 23 \\
\hline 7 July 2017 & 16 & 9 & 8 & 17 \\
\hline 17 July 2017 & 13 & 5 & 11 & 18 \\
\hline 2 August 2017 & 6 & 12 & 5 & 20 \\
\hline 15 August 2017 & 11 & 9 & 12 & 12 \\
\hline 29 August 2017 & 9 & 4 & 5 & 8 \\
\hline 11 September 2017 & 7 & 5 & 4 & 6 \\
\hline 29 September 2017 & 6 & 0 & 0 & 5 \\
\hline 12 October 2017 & 5 & 2 & 2 & 2 \\
\hline 21 October 2017 & 2 & 0 & 0 & $\mathbf{5 0}$ \\
\hline 2 total species & $\mathbf{4 4}$ & $\mathbf{3 2}$ & $\mathbf{3 7}$ & \\
\hline
\end{tabular}

\section{RESULTS}

A total of 1147 individuals were recorded on Avala Mt., representing 50 species (Tab. 2, Fig. 7). The highest number (44) of butterfly species was recorded in sector A and the lowest (32) in sector $\mathrm{B}$ (Tab. 1). The sector $\mathrm{A}$ had the highest average number of species, abundance of individuals, with the lowest proportion of singletons, per sampling unit (Tab. 3). In contrast, sector B had the lowest average number of species and abundance of individuals per unit but a similar proportion of singletons as the sector $\mathrm{C}$.

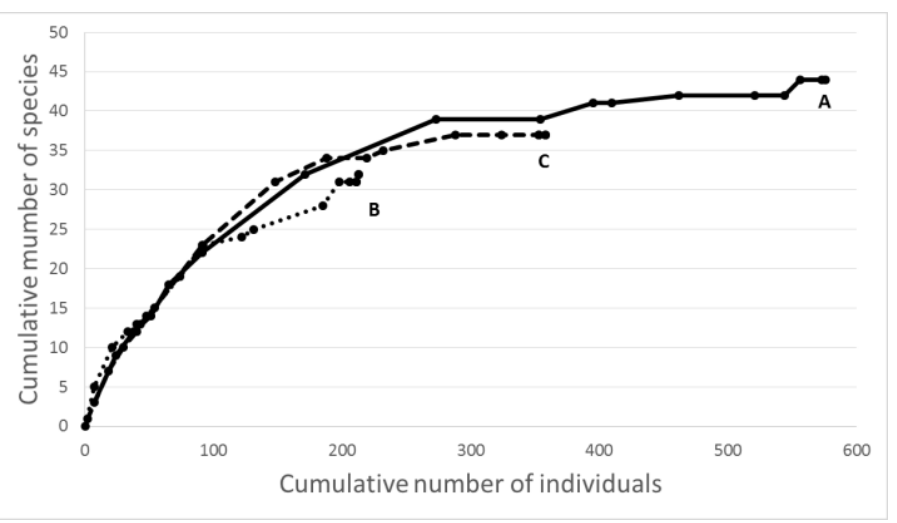

Figure 3. Cumulative number of butterfly species plotted against the cumulative number of individuals observed in each sector.

According to species accumulation curves in relation to the number of individuals (Fig. 3), sector B had the largest potential for collection of undetected species. The species accumulation curve in sector $\mathrm{A}$, on the other hand, has reached an asymptote. A sample-biased species accumulation curve (Fig. 4) implied that the number of species stabilized at about 30 sampling units and that enough sampling effort had been invested to estimate the butterfly species diversity at selected sectors in one season.

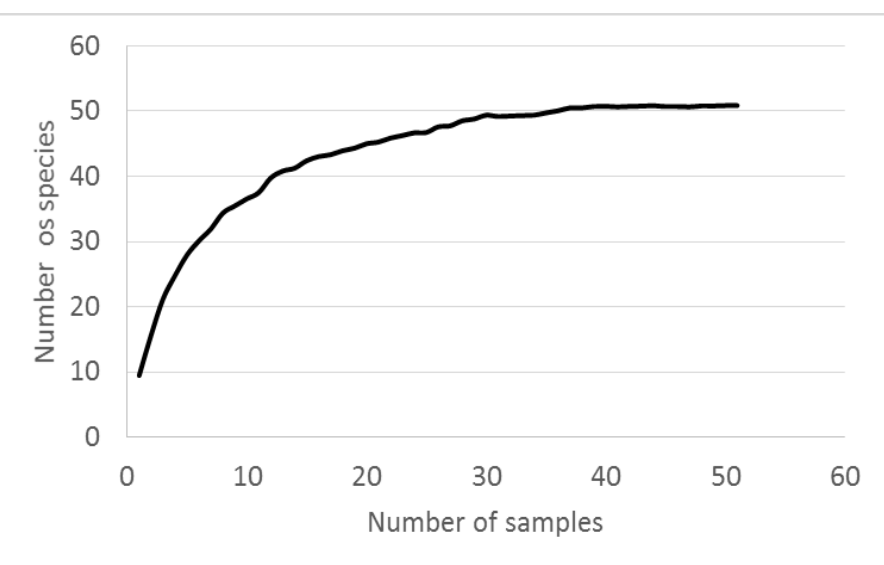

Figure 4. Species accumulation curve of abundance-based estimator Chao1 against the sampling effort for the complete dataset (51 samples).

The highest butterfly species richness (29) and abundance of individuals (177) was recorded on $23^{\text {rd }}$ June 2017 (Tab. 1, Fig. 5). Butterfly phenology was highly correlated to temperature. Correlation between the temperature on sampling days and the number of species was $0.56(\mathrm{p}=0.020)$ and the number of individuals $0.65 \quad(\mathrm{p}=0.004)$. In August, when temperatures peaked, the species number and abundance of individuals dropped (Fig. 5).

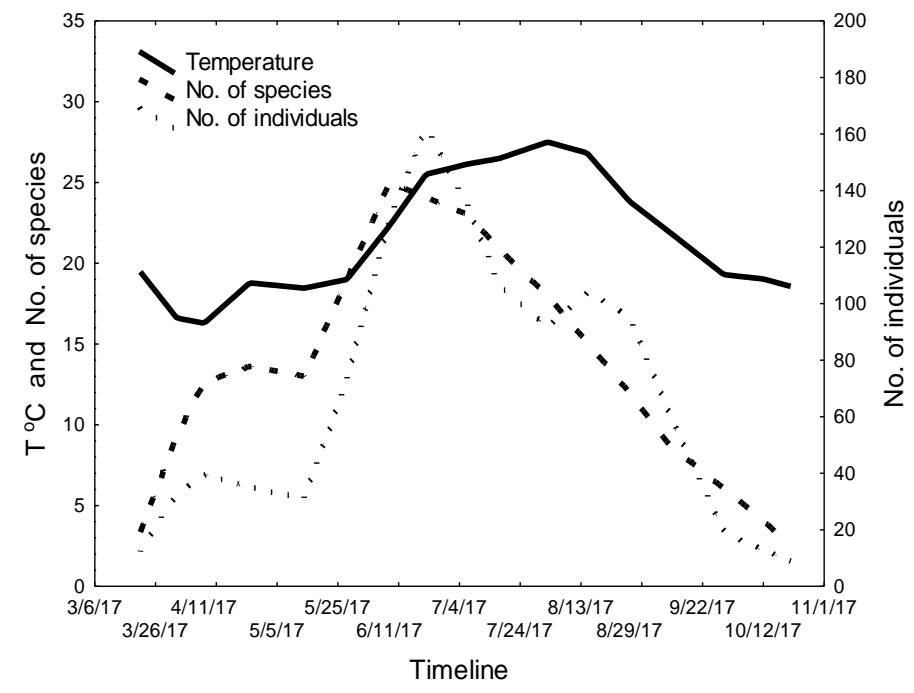

Figure 5. Day temperatures, predicted values of the observed species richness and abundance of individuals on the Avala Mt. 
On Avala Mt., trophic specialisations of caterpillars of the observed species were as follows: monophagous (36\%), oligophagous (42\%), polyphagous (22\%) (Tab. 2). Most of the butterfly species were mesophilic $(76.5 \%)$ and mesothermophilic (13.7\%) (Tab. 2). Nevertheless, a thermophilic species Iphiclides podalirius was one of the most abundant species at sector A. According to habitat types, the observed species were characteristic mostly for grasslands (38.4\%) and forests $(34.3 \%)$.

Two forest species (Neptis sappho and Pararge aegeria, Tab. 2) were most abundant in sector B. $52 \%$ of the observed species belonged to the Euro-Siberian faunal group, followed by the Euro-Oriental (30\%) and Holartic (10\%) group (Fig. 6).

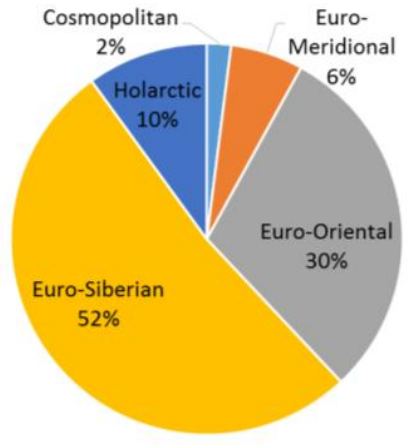

Figure 6. Zoogeographic composition of 50 examined species on Avala Mt. transect area.

Table 2. Abundance of observed species of butterflies during 2017 for three sectors on Avala Mt., with butterfly biological characteristics. i) Species abundance (Quantitative distribution in sectors A, B and C; total number of specimens). ii) Ecological characteristics: TS = Trophic specialisation of caterpillars - monophagous $(\mathrm{m})$, oligophagous $(\mathrm{o})$, polyphagous $(\mathrm{p})$; $\mathrm{T}=$ Preferences according to habitats temperature - Xerothermophile (Xt), Thermophile (T), Moesothermophile (Mt), Mesophile (M); H = Characteristics according to habitat types: HS - Heath and Scrub, Gr - Grassland, Fo - Forest, We - Wetland, Un - Unvegetable, Ag - Agriculture, Ur - Urban. iii) FE = Zoogeographical characteristics - "faunal elements": Cosmopolitan (4), Euro-Meridional (5), Euro-Oriental (6), Euro-Siberian (7), Holarctic (8).

\begin{tabular}{|c|c|c|c|c|c|c|c|c|}
\hline \multirow[t]{2}{*}{ Nb. } & \multirow[t]{2}{*}{ Scientific names } & \multicolumn{4}{|c|}{ Species abundance } & \multicolumn{2}{|c|}{$\begin{array}{c}\text { Ecological } \\
\text { characteristics }\end{array}$} & \multirow[t]{2}{*}{ FE } \\
\hline & & $\mathbf{A}$ & $\mathbf{B}$ & $\mathbf{C}$ & $\begin{array}{l}\text { TOTAL } \\
(\mathrm{A}+\mathrm{B}+\mathrm{C})\end{array}$ & TS/T & $\mathbf{H}$ & \\
\hline & $\begin{array}{l}\text { LEPIDOPTERA Linnaeus, } 1758 \\
\text { PAPILIONOIDEA Latreille, } 1802\end{array}$ & & & & & & & \\
\hline & Fam. Papilionidae Latreille, 1802 & & & & & & & \\
\hline 1 & Iphiclides podalirius (Linnaeus, 1758) & 50 & 0 & 18 & 68 & $\mathrm{o} / \mathrm{T}$ & HS/Gr/Ag & 6 \\
\hline \multirow[t]{2}{*}{2} & Papilio machaon Linnaeus, 1758 & 3 & 1 & 8 & 12 & $\mathrm{p} / \mathrm{M}$ & $\mathrm{Gr} / \mathrm{Ur}$ & 7 \\
\hline & Fam. Hesperiidae Latreille, 1809 & & & & & & & \\
\hline 3 & Erynnis tages (Linnaeus, 1758) & 10 & 0 & 6 & 16 & $\mathrm{o} / \mathrm{M}$ & $\mathrm{Gr}$ & 7 \\
\hline 4 & Pyrgus malvae (Linnaeus, 1758) & 19 & 4 & 15 & 38 & $\mathrm{p} / \mathrm{M}$ & $\mathrm{Gr}$ & 7 \\
\hline 5 & Thymelicus lineola (Ochsenheimer, 1806) & 24 & 4 & 13 & 41 & $\mathrm{o} / \mathrm{M}$ & $\mathrm{Gr} / \mathrm{Ur}$ & 8 \\
\hline 6 & Thymelicus sylvestris (Poda, 1761) & 6 & 1 & 3 & 10 & $\mathrm{o} / \mathrm{M}$ & $\mathrm{Gr} / \mathrm{Fo}$ & 6 \\
\hline \multirow[t]{2}{*}{7} & Ochlodes sylvanus (Esper, 1777) & 14 & 3 & 7 & 24 & $\mathrm{o} / \mathrm{M}$ & $\mathrm{Gr} / \mathrm{Fo}$ & 7 \\
\hline & Fam. Pieridae Swainson, 1820 & & & & & & & \\
\hline 8 & Leptidea sinapis (Linnaeus, 1758) complex & 11 & 8 & 5 & 24 & $\mathrm{o} / \mathrm{M}$ & $\mathrm{Gr} / \mathrm{Fo}$ & 7 \\
\hline 9 & Anthocharis cardamines (Linnaeus, 1758) & 6 & 4 & 4 & 14 & $\mathrm{o} / \mathrm{M}$ & $\mathrm{Gr} / \mathrm{Fo}$ & 7 \\
\hline 10 & Pieris brassicae (Linnaeus, 1758) & 16 & 13 & 3 & 32 & $\mathrm{p} / \mathrm{M}$ & $\mathrm{Gr} / \mathrm{Ag} / \mathrm{Ur}$ & 7 \\
\hline 11 & Pieris mannii (Mayer, 1851) & 0 & 4 & 4 & 8 & $\mathrm{o} / \mathrm{Mt}$ & HS/Fo & 6 \\
\hline 12 & Pieris rapae (Linnaeus, 1758) & 40 & 16 & 19 & 75 & $\mathrm{p} / \mathrm{M}$ & $\mathrm{Ag} / \mathrm{Ur}$ & 8 \\
\hline 13 & Pieris napi (Linnaeus, 1758) & 26 & 7 & 5 & 38 & $\mathrm{o} / \mathrm{M}$ & $\mathrm{Gr} / \mathrm{Fo} / \mathrm{Ag}$ & 7 \\
\hline 14 & Colias croceus (Fourcroy, 1785) & 1 & 0 & 1 & 2 & $\mathrm{o} / \mathrm{Mt}$ & $\mathrm{Gr} / \mathrm{Ag}$ & 6 \\
\hline \multirow[t]{2}{*}{15} & Gonepteryx rhamni (Linnaeus, 1758) & 1 & 0 & 1 & 2 & $\mathrm{~m} / \mathrm{M}$ & $\mathrm{Fo} / \mathrm{HS}$ & 7 \\
\hline & Fam. Nymphalidae Rafinesque, 1815 & & & & & & & \\
\hline 16 & Issoria lathonia (Linnaeus, 1758) & 0 & 3 & 1 & 4 & $\mathrm{~m} / \mathrm{M}$ & $\mathrm{Gr} / \mathrm{Ag} / \mathrm{HS}$ & 7 \\
\hline 17 & Brenthis daphne (Bergsträsser, 1780) & 7 & 0 & 0 & 7 & $\mathrm{~m} / \mathrm{M}$ & $\mathrm{Gr} / \mathrm{Fo}$ & 7 \\
\hline 18 & Brenthis hecate (Denis \& Schiffermüller, 1775) & 3 & 0 & 0 & 3 & $\mathrm{~m} / \mathrm{M}$ & $\mathrm{Gr} / \mathrm{Fo}$ & 7 \\
\hline 19 & Argynnis paphia (Linnaeus, 1758) & 20 & 13 & 27 & 60 & $\mathrm{~m} / \mathrm{M}$ & Fo & 7 \\
\hline 20 & Argynnis aglaja (Linnaeus, 1758) & 1 & 0 & 0 & 1 & $\mathrm{~m} / \mathrm{M}$ & $\mathrm{Gr} / \mathrm{Fo}$ & 7 \\
\hline 21 & Araschnia levana (Linnaeus, 1758) & 1 & 9 & 0 & 10 & $\mathrm{~m} / \mathrm{M}$ & Fo/Gr & 7 \\
\hline 22 & Vanessa atalanta (Linnaeus, 1758) & 7 & 1 & 0 & 8 & $\mathrm{o} / \mathrm{M}$ & $\mathrm{Gr} / \mathrm{Fo}$ & 8 \\
\hline 23 & Vanessa cardui (Linnaeus, 1758) & 1 & 0 & 0 & 1 & $\mathrm{p} / \mathrm{M}$ & $\mathrm{Gr} / \mathrm{Fo} / \mathrm{Ur}$ & 4 \\
\hline 24 & Aglais io (Linnaeus, 1758) & 5 & 0 & 8 & 13 & $\mathrm{~m} / \mathrm{M}$ & $\mathrm{Gr} / \mathrm{Fo} / \mathrm{Ur}$ & 7 \\
\hline
\end{tabular}




\begin{tabular}{|c|c|c|c|c|c|c|c|c|}
\hline \multirow[t]{2}{*}{ Nb. } & \multirow[t]{2}{*}{ Scientific names } & \multicolumn{4}{|c|}{ Species abundance } & \multicolumn{2}{|c|}{$\begin{array}{c}\text { Ecological } \\
\text { characteristics }\end{array}$} & \multirow[t]{2}{*}{ FE } \\
\hline & & $\mathbf{A}$ & $\mathbf{B}$ & $\mathbf{C}$ & $\begin{array}{c}\text { TOTAL } \\
(\mathbf{A}+\mathbf{B}+\mathbf{C})\end{array}$ & TS/T & $\mathbf{H}$ & \\
\hline 25 & Aglais urticae (Linnaeus, 1758) & 2 & 0 & 0 & 2 & $\mathrm{~m} / \mathrm{M}$ & $\mathrm{Gr} / \mathrm{Fo} / \mathrm{Ur}$ & 7 \\
\hline 26 & Polygonia c-album (Linnaeus, 1758) & 2 & 10 & 1 & 13 & $\mathrm{p} / \mathrm{M}$ & $\mathrm{Fo} / \mathrm{Ag}$ & 7 \\
\hline 27 & Melitaea athalia (Rottemburg, 1775) & 26 & 0 & 14 & 40 & $\mathrm{o} / \mathrm{M}$ & $\mathrm{Gr} / \mathrm{Fo}$ & 5 \\
\hline 28 & Limenitis reducta (Staudinger, 1901) & 0 & 1 & 0 & 1 & $\mathrm{~m} / \mathrm{Xt}$ & Fo/HS & 6 \\
\hline 29 & Neptis sappho (Pallas, 1771) & 2 & 30 & 0 & 32 & $\mathrm{~m} / \mathrm{M}$ & Fo & 7 \\
\hline 30 & Kirinia roxelana (Cramer, 1777) & 6 & 0 & 0 & 6 & $\mathrm{p} / \mathrm{Xt}$ & Fo/HS & 6 \\
\hline 31 & Pararge aegeria (Linnaeus, 1758) & 0 & 22 & 0 & 22 & $\mathrm{o} / \mathrm{M}$ & Fo & 6 \\
\hline 32 & Lasiommata megera (Linnaeus, 1767) & 15 & 7 & 1 & 23 & $\mathrm{o} / \mathrm{M}$ & $\mathrm{Gr} / \mathrm{Fo}$ & 6 \\
\hline 33 & Coenonympha arcania (Linnaeus, 1760 ) & 2 & 3 & 5 & 10 & $\mathrm{o} / \mathrm{M}$ & $\mathrm{Gr} / \mathrm{Fo}$ & 5 \\
\hline 34 & Coenonympha pamphilus (Linnaeus, 1758) & 18 & 1 & 19 & 38 & $\mathrm{o} / \mathrm{M}$ & $\mathrm{Gr}$ & 6 \\
\hline 35 & Maniola jurtina (Linnaeus, 1758) & 52 & 23 & 46 & 121 & $\mathrm{o} / \mathrm{M}$ & $\mathrm{Gr} / \mathrm{Fo} / \mathrm{Ag}$ & 6 \\
\hline 36 & Melanargia galathea (Linnaeus, 1758) & 25 & 1 & 30 & 56 & $\mathrm{p} / \mathrm{M}$ & $\mathrm{Gr} / \mathrm{Fo}$ & 6 \\
\hline 37 & Brintesia circe (Fabricius, 1775) & 10 & 1 & 11 & 22 & $\mathrm{o} / \mathrm{Mt}$ & $\mathrm{Fo} / \mathrm{Gr}$ & 6 \\
\hline \multirow[t]{2}{*}{38} & Minois dryas (Scopoli, 1763) & 2 & 0 & 3 & 5 & $\mathrm{o} / \mathrm{Mt}$ & $\mathrm{Gr} / \mathrm{Fo}$ & 7 \\
\hline & Fam. Riodinidae Grote, 1895 & & & & & & & \\
\hline \multirow[t]{2}{*}{39} & Hamearis lucina (Linnaeus, 1758) & 0 & 3 & 0 & 3 & $\mathrm{~m} / \mathrm{M}$ & $\mathrm{Gr} / \mathrm{Fo}$ & 5 \\
\hline & Fam. Lycaenidae Leach, 1815 & & & & & & & \\
\hline 40 & Cupido argiades (Pallas, 1771) & 10 & 6 & 7 & 23 & $\mathrm{o} / \mathrm{M}$ & $\mathrm{Gr} / \mathrm{Fo}$ & 8 \\
\hline 41 & Celastrina argiolus (Linnaeus, 1758) & 1 & 9 & 2 & 12 & $\mathrm{p} / \mathrm{M}$ & Fo/Ag & 7 \\
\hline 42 & Plebeius argus (Linnaeus, 1758) & 23 & 0 & 8 & 31 & $\mathrm{p} / \mathrm{M}$ & $\mathrm{HS} / \mathrm{Gr} / \mathrm{Fo}$ & 7 \\
\hline 43 & Plebeius idas (Linnaeus, 1760) & 6 & 0 & 2 & 8 & $\mathrm{p} / \mathrm{M}$ & $\mathrm{Gr} / \mathrm{Fo}$ & 8 \\
\hline 44 & Aricia agestis (Denis \& Schiffermüller, 1775) & 7 & 0 & 3 & 10 & $\mathrm{~m} / \mathrm{M}$ & $\mathrm{Gr}$ & 7 \\
\hline 45 & Polyommatus icarus (Rottemburg, 1775) & 73 & 4 & 50 & 127 & $\mathrm{o} / \mathrm{M}$ & $\mathrm{Gr} / \mathrm{Ur}$ & 7 \\
\hline 46 & Lycaena dispar (Haworth, 1802) & 1 & 0 & 1 & 2 & $\mathrm{~m} / \mathrm{Hg}$ & $\mathrm{Gr} / \mathrm{We}$ & 7 \\
\hline 47 & Lycaena tityrus (Poda, 1761) & 19 & 0 & 5 & 24 & $\mathrm{~m} / \mathrm{M}$ & $\mathrm{Gr}$ & 7 \\
\hline 48 & Lycaena thersamon (Esper, 1784) & 1 & 0 & 1 & 2 & $\mathrm{~m} / \mathrm{Mt}$ & $\mathrm{Gr} / \mathrm{Ur}$ & 6 \\
\hline 49 & Satyrium acaciae (Fabricius, 1787) & 1 & 0 & 1 & 2 & $\mathrm{~m} / \mathrm{Mt}$ & HS & 6 \\
\hline \multirow[t]{2}{*}{50} & Favonius quercus (Linnaeus, 1758) & 0 & 1 & 0 & 1 & $\mathrm{~m} / \mathrm{Mt}-\mathrm{Xt}$ & Fo & 6 \\
\hline & Total & 576 & 213 & 358 & 1147 & & & \\
\hline
\end{tabular}

Table 3. Descriptive statistics of species richness and abundance of individuals per sampling unit; Mean \pm Standard deviation, Median in the three sectors surveyed (A, B, C), with numbers of singletons, Shannon diversity index and the most common species.

\begin{tabular}{|c|c|c|c|c|}
\hline Sector & A & B & C & Total \\
\hline $\begin{array}{c}\text { Species Average } \pm \text { StD } \\
\text { Median }\end{array}$ & $9.4 \pm 6.1$ & $5.5 \pm 4.0$ & $6.1 \pm 5.1$ & $13.4 \pm 7.8$ \\
13
\end{tabular}



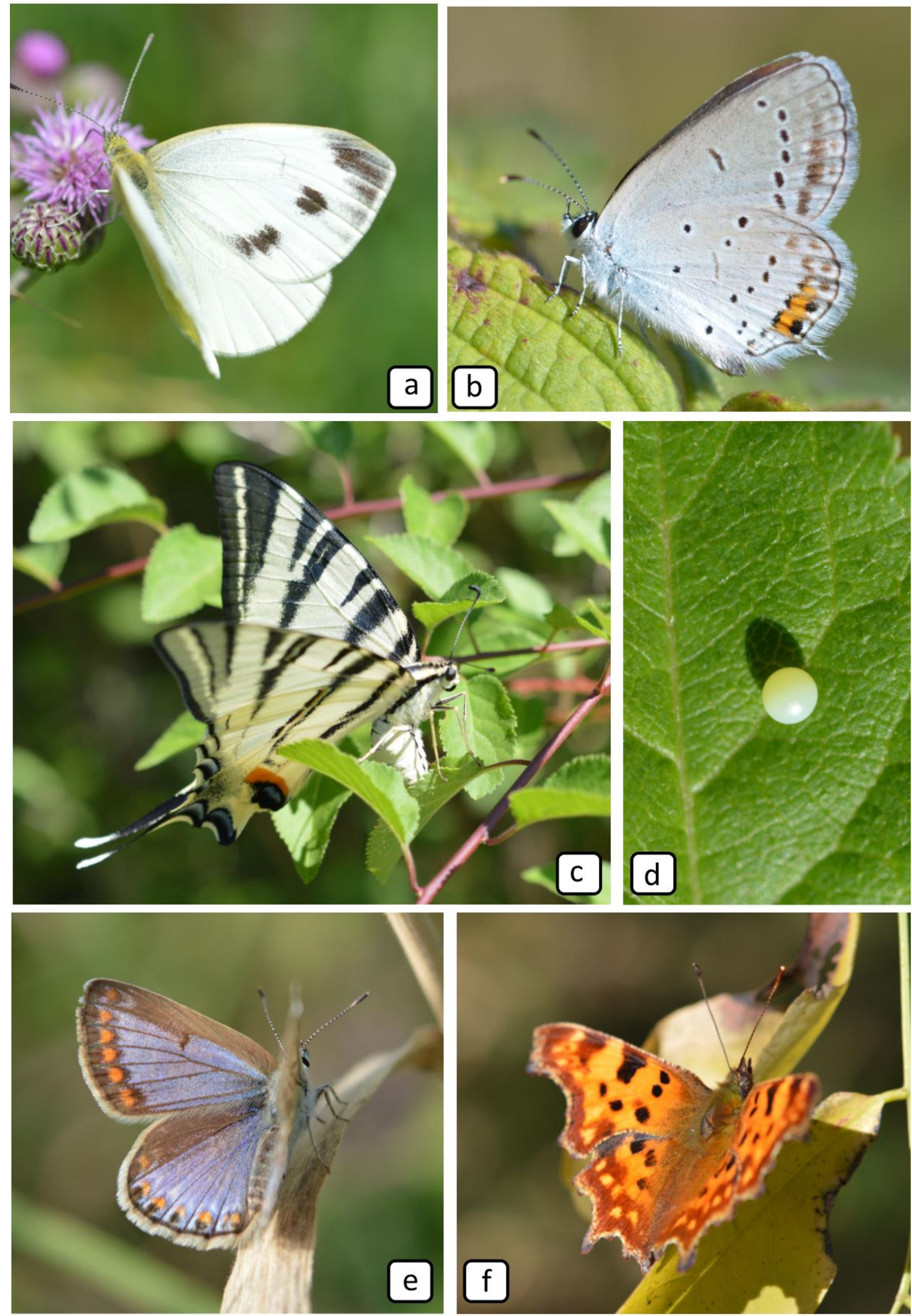

Figure 7. Some of the observed species: a) Pieris mannii (Mayer, 1851), new species for Avala Mt.; b) Cupido argiades (Pallas, 1771), species found in all three sectors; c \& d) Iphiclides podalirius Linnaeus, 1758, a female depositing eggs on Prunus spinosa, deposited egg; e). Polyommatus icarus Rottemburg, 1775, a complete gynandromorph; f). Polygonia c-album Linnaeus, 1758, third generation (All photos P. Jakšić). 


\section{DISCUSSION}

A total of 50 species of butterflies were recorded in the three sectors on Avala Mt. in 2017, representing $45 \%$ of the total number of butterfly species previously known to the Avala Mt. (111 species; Jakšić, 2015).

Three new species for the fauna of Avala Mt. were found: Pieris mannii (Mayer, 1851), Satyrium acaciae (Fabricius, 1787) and Kirinia roxelana (Cramer, 1777).

Euro-Siberian and Euro-Oriental butterfly species represented $82 \%$ of the basic faunal features of the Avala Mt. Most of the observed butterfly species were mesophilic $(76.5 \%)$.

Sector A - dry grassland with ongoing secondary succession after 20 years of agricultural abandonment - was the area with the highest butterfly diversity and abundance. Among the three sectors, the highest Shannon's index for sector A suggested not only the highest species diversity but also evenness of distribution with the lowest number of singletons.

Sector B covered with natural forest vegetation supported the lowest number of species and individuals.

Sector A and C, which are both former agricultural landscapes, proved important for the biodiversity of butterflies on the Avala Mt. Abandoned dry grasslands with ongoing secondary succession have the highest plant biodiversity (Paušič et al., 2017). According to van Swaay \& Warren (2006) abandonment of traditional land use is one of the major threats to Prime Butterfly Areas (PBAs). Grassland abandonment has a strong effect on butterfly diversity, especially on grassland specialists which are substituted by common butterflies, less important for conservation purposes (Stefanescu et al., 2009). Our results show that the observed butterfly species on Avala Mt., which is a PBA area, were almost equally characteristic for grasslands (38.4\%) and forests $(34.3 \%)$. This means that butterfly biodiversity on Avala Mt. depends on habitat diversity, which is a combination of climax forest vegetation as well as formerly agricultural landscapes in different stages of succession.

\section{ACKNOWLEGMENTS}

We are grateful to Dr Ana Savić, University of Niš, Faculty of Sciences and Miloš Jović, Natural History Museum, Belgrade for their valuable assistance and useful advices.

\section{REFERENCES}

Anđus, Lj. 2008. Butterflies (Lepidoptera: Hesperioidea \& Papilionoidea) from the collection of the Natural History Museum in Belgrade. Belgrade: Natural History Museum. Special issue 40: 1-94, 6 figs. [In English, Serbian summary].
Anonymous, 2017. Weather in Serbia. Daily \& Monthly climate characteristics for the territory of Serbia.Republic: Hydrometeorological Service of Serbia. Web: http://www.hidmet.gov.rs/eng/download/index.php.

Bohn, U., Neuhäusl, R., Gollub, G., Hettwer, C., Neuhäuslová, Z., Raus, Th., Schlüter, H. \& Weber, H. 2000. Karte der natürlichen Vegetation Europas Maßstab 1: 2500000 / Map of the NaturalVegetation of Europe. Scale 1:2500000. Münster: Landwirtschaftsverlag. 200/2003.

Colwell, R.K. 2013. EstimateS: Statistical estimation of species richness and shared species from samples. Version 9. User's Guide and application at http://purl.oclc.org/estimates.

Dimitrijević, B. 1931. Avala, petrografsko-mineraloška studija, sa geološkom kartom u razmeri 1: 50. 000. In Prirodnjački i matematički spisi. Beograd: Srpska kraljevska akademija. Posebna izdanja, Knjiga LXXXV, Knjiga 23: 1-150. [In Serbian].

Fukarek, P., Jovanović, B., \& eds., 1986. Karta Prirodne Potencijalne Vegetacije SFR Jugoslavije, 1: $1000000 /$ Natural potential vegetation of the SFR Jugoslavia, 1: 1 000 000. In B. Jovanović, R. Jovanović, \& M. Zupančič Eds., Prirodna Potencijalna Vegetacija Jugoslavije. Ljubljana.

Gradojević, M. 1930. Leptirovi Srbije I - Diurna. (Les papillons de Serbie I. Diurna). Glasnik Jugoslovenskog entomoloskog društva, Beograd, 1930-31; V-VI (1-2): 133-158, [In Serbian].

Gušić, B. 1923. Ein Beitrag zur Rophaloceren-Fauna Serbiens. Verhandlungen der K. K. Zoologisch-botanischen Gesellschaft in Wien, 72: (12)-(13).

Jaksic, P. 2015. Aspects of butterfly zoogeography of some Pannonian island mountains. Matica Srpska Journal for Natural Sciences, 128, pp. 7-19. doi:10.2298/zmspn1528007j

Jakšić, P., Verovnik, R., \& Dodok, I. 2008. Overview of Prime Butterfly Areas in Serbia / Pregled Odabranih područja za dnevne leptire u Srbiji. In P. Jakšić Ed., Odabrana područja za dnevne leptire: Put za ostvarenje zaštite prirode u Srbiji / Prime Butterfly Areas in Serbia: A tool for nature conservation in Serbia. Beograd: Habiprot Ed.. 43-203. [In Serbian and English].

Karadžić, B., \& Marinković, S. 2009. Kvantitativna ekologija.Beograd: Institut za biološka istraživanja "Siniša Stanković". pp. 489 [In Serbian]

Kudrna, O., Pennerstorfer, J., \& Lux, K. 2015. Distribution atlas of European butterflies and skippers.Schwanfeld, Germany: istribution atlas of European butterflies and skippers. Wissenschaftlicher Verlag Peks i. K.

Mihut, S., \& Dincã, V. 2004. Fluturii de zi din Romãnia. Biodiv. Cluj., 1: 18-31. [In Romanian]

Moucha, J. 1966. Zur Kenntnis der Schmetterlingsfauna Jugoslawiens (Lepidoptera). Entomologische Nachrichten, 10(4): 49-53.

Nieukerken, V., \& et al., 2011. Order Lepidoptera Linnaeus, 1758. In: Zhang, Z. Q. (Ed.) Animal biodiversity: An outline of higher-level classification and survey of taxonomic richness. Zootaxa, 3148(1), pp. 211-221.

Paušič, I., Ivajnšič, D., Kaligarič, M., \& Pipenbaher, N. 2017. Relation between plant species diversity and landscape 
variables in Central-European dry grassland fragments and their successional derivates. Acta Botanica Croatica, 76(2). doi:10.1515/botcro-2017-0001

Pollard, E. 1977. A method for assessing changes in the abundance of butterflies. Biological Conservation, 12(2), pp. 115-134. doi:10.1016/0006-3207(77)90065-9

Statistica. 2004. Statistica 7.0.Stat Soft Inc.

Stefanescu, C., Carnicer, J., \& Peñuelas, J. 2010. Determinants of species richness in generalist and specialist Mediterranean butterflies: the negative synergistic forces of climate and habitat change. Ecography, 34(3), pp. 353-363. doi:10.1111/j.1600-0587.2010.06264.x
Stefanescu, C., Peñuelas, J., \& Filella, I. 2009. Rapid changes in butterfly communities following the abandonment of grasslands: a case study. Insect Conservation and Diversity, 2(4), pp. 261-269. doi:10.1111/j.17524598.2009.00063.x

van Swaay, C.A.M.A., \& Warren, M.S. 2006. Prime Butterfly Areas of Europe: An Initial Selection of Priority Sitesfor Conservation. Journal of Insect Conservation, 10(1), pp. 511. doi:10.1007/s10841-005-7548-1

van Swaay, C., Warren, M., \& Loïs, G. 2006. Biotope Use and Trends of European Butterflies. Journal of Insect Conservation, 10(2), pp. 189-209. doi:10.1007/s10841006-6293-4 